\title{
Editorial \\ El futuro de las revistas nacionales indexadas
}

Henry Acuña Barrantes

En esta oportunidad estamos presentando el Vol.10 No.1 que corresponde al primero de dos ediciones programadas para 2017. Nuestra tarea para esta edición de la Revista Academia $y$ Virtualidad consiste en asumir los nuevos lineamientos que Publindex implementó para revistas dedicadas a procesos, resultados y conclusiones reflexivas en pro de la investigación científica en y desde el entorno académico.

La Revista Academia y Virtualidad, en estos tres últimos años, ha registrado cambios importantes gracias al incondicional apoyo de la Vicerrectoría de Investigaciones y de la Facultad de Estudios a Distancia; asimismo, han sido valiosos el tiempo dedicado y facilitado al editor en jefe, la implementación del Open Journal System (OJS), la adquisición de los DOI, las capacitaciones a sus editores, entre otros aspectos vitales para todo este proceso de cualificación. Todo ello ha repercutido positivamente en crecimiento y visibilidad de nuestra revista, pues hasta la fecha es una publicación de consulta en la mayoría de ciudades del territorio nacional y en más de 80 países de los cinco continentes (Fuente: Google Analytics).

\section{Estadísticas, Revista Academia y \\ Virtualidad (2014-2016)}

Estadísticas, Revista Academia y Virtualidad (2014-2016)

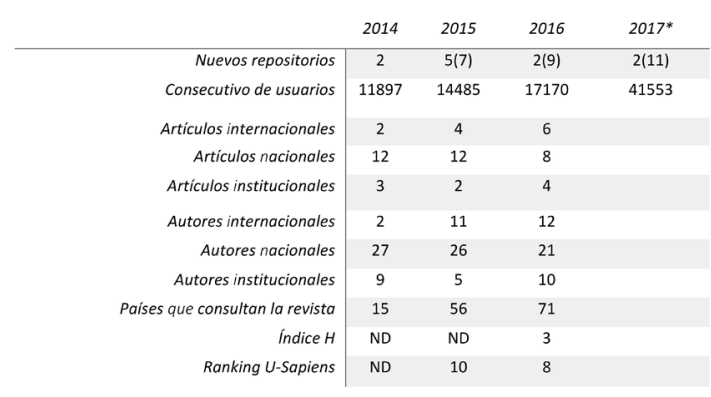

Fuente: Revista Academia y Virtualidad ("febrero)

\section{Futuro de las revistas indexadas}

Publindex, como ente regulador de las revistas científicas nacionales, proporciona directrices para su clasificación $(\mathrm{C}, \mathrm{B}$, $\left.A_{2}, A_{1}\right)$. Las universidades que apoyan la difusión de revistas o desean producir nuevas publicaciones científicas, deben realizar evaluación tanto cualitativa como cuantitativa de sus volúmenes, teniendo como referente importante su misión y visión, dado que se puede registrar visibilidad e impacto, pero en ocasiones no estar clasificada a nivel nacional aunque sí internacionalmente; por ello la importancia y claridad de lo que pretenden las universidades con sus ediciones.

\footnotetext{
${ }^{1}$ Vigentes a 2017
} 
Sobre este tema hay mucha tela de dónde cortar, pero por ahora abordaré un solo aspecto: la visibilidad e impacto en los lectores, específicamente los estudiantes que desean tener de primera mano los resultados de investigación más recientes de parte de algunos profesores-investigadores, quienes "infortunadamente" no logran interesarse en este tipo de ejercicio creador y analítico y no motivan a sus estudiantes a consultarlas.

No obstante, el interés nuestro, el de la Revista Academia y Virtualidad, y la propia Facultad con sus docentes y grupos de investigación consiste en impulsar permanentemente la búsqueda para que sus estudiantes consulten, se interesen y estén al día en las temáticas que maneja la revista. En esa medida se ha generado interés por procesos investigativos y creativos relacionados con la academia y la virtualidad a fin de mejorar la educación en diversos escenarios profesionales. Por ello, nuestra perspectiva en pos del futuro de una revista como la nuestra (cuya preocupación también es la de la mayoría de publicaciones científicas de nuestro país), que consiste en tener siempre presente una cualificación continua, ceñida al sistema nacional de referencia para la evaluación de publicaciones científicas con rigor y criterio. Todo esto, sumado al recurso humano, a las condiciones y al interés de la academia, que de alguna manera redundarán en coherencia con la gran dinámica contemporánea jalonada por las tecnologías de punta.

Con este volumen cierro un ciclo importante al frente de la Revista. Se ha cumplido el tiempo desde enero de 2014 hasta esta fecha en que permanecí como editor de Academia y Virtualidad. En esta labor encontré muchas sinergias que contribuyeron a la consolidación de la revista, además de enriquecer mi bagaje personal con nuevos conocimientos y experiencias. Nuestra publicación desde entonces se ha caracterizado por exponer artículos y ensayos con rigor científico, de parte de uno o varios autores, mediante un proceso de selección exhaustivo con base en criterios de calidad igualmente exigentes, para ingresar y consolidar una base de datos indexada.

Finalmente, a partir de este momento estaré en otras actividades propias de la universidad. Y desde ahora, la responsabilidad de la edición próxima estará a cargo del Ingeniero Carlos Gaviria Mendoza PhD, a quien le deseo los mejores éxitos en este fascinante rol como editor. Sólo me resta agradecer a los miembros de nuestros Comités Editorial y Científico, a los árbitros evaluadores quienes con su apoyo permanente hicieron de mi labor algo enriquecedor, al igual que a investigadores, ponentes, expertos en propuestas, equipos de revisión técnica, corrección de estilo y traducción, que desde su experticia contribuyeron a cualificar cada edición.

$* * * * * * * * * * * * * * * * * * * * * * * * * * * * * * * * * * * *$

Continuamos con nuestra tradicional presentación de los artículos. En este volumen 10 No. 1, la Revista Academia y Virtualidad pone a disposición artículos de destacados investigadores nacionales e internacionales. El contenido expone y continúa los lineamientos y orientaciones establecidos por la Dirección de la Revista, en cabeza del ingeniero Martin Villamil Rozo, Decano de la Facultad de Estudios a Distancia, del Comité Editorial y del Comité Científico.

A continuación se presentan nueve artículos de investigación, reflexión y revisión, resultados de ejercicios investigativos. Por una parte, se destacan los artículos que muestran un trabajo basado en las diferentes 
problemáticas educativas, en particular aquellas que involucran las TIC y todos aquellos aspectos que, en una $\mathrm{u}$ otra medida, cimientan la educación virtual. En el primer documento, las investigadoras Vargas y García, de la Universidad de Ibagué, presentan el artículo de investigación científica titulado "Competencias directivas, un reto para la educación superior", cuyo estudio tiene como objetivo determinar el nivel de importancia de las competencias genéricas y específicas del administrador financiero, tomando como referente el proyecto Tuning en LatinoaméricaEuropa y el proyecto GRIICA Colombia. Por otro lado, el profesor Anívar Chaves Torres, en su trabajo de investigación "La educación a distancia como respuesta a las necesidades educativas del siglo XXI", se enfoca en establecer cómo la educación a distancia se erige como respuesta viable a la extensa demanda de educación, particularmente por personas que por diferentes circunstancias no pueden acceder a la educación presencial.

Los investigadores Rodríguez y Vílchez presentan un artículo de investigación, titulado "Valor agregado como indicador de calidad en programasacadémicosuniversitariosutilizando resultados de pruebas censales", cuyo estudio consistió en determinar el valor agregado como indicador de calidad de un programa académico teniendo en cuenta dos momentos de la vida académica de los estudiantes de una cohorte y la construcción de una explicación razonada de esta valoración a partir del aporte que hace la universidad. Continuando con los artículos de este volumen, la doctora Issa Fontalvo, en su trabajo de investigación "Habilidades del liderazgo para una cultura de innovación en la gerencia de las universidades del Distrito de Santa Marta", indica que el propósito fundamental de su investigación fue analizar las habilidades del liderazgo para una cultura de innovación en la gerencia de las universidades del Distrito de Santa Marta. En el desarrollo del trabajo se indica que la gerencia no posee capacidad para darse cuenta de que algo ha pasado desapercibido, carece del manejo de situaciones difíciles de manera reflexiva y no escucha; entonces, se recomienda elaborar talleres o cursos de formación sobre habilidades gerenciales para una cultura de innovación a fin de obtener un cambio en el comportamiento gerencial hacia una gerencia mediante un pensamiento estratégico innovador.

A su vez, los profesores Amaya y Rincón presentan un resultado de investigación sobre la "Evaluación de la autorregulación académica en estudiantes de pregrado de la Corporación Universitaria Minuto de Dios-UNIMINUTO, en la modalidad virtual distancia", cuyo estudio tuvo como objetivo evaluar estrategias de autorregulación académica implementadas por los estudiantes de pregrado de dicha entidad.

Con respecto al trabajo "Normatividad y estrategias de formación de profesores en tecnologías de lainformación y comunicación", los investigadores López, Rojas, Correa y Arbeláez de la Universidad de la Amazonia, exponen que el propósito de la formación en TIC es obtener competitividad, calidad y equidad de la educación. Las estrategias de formación de profesores se han realizado por niveles y han privilegiado la técnica de cascada. Una de sus conclusiones indica que varias de las estrategias de formación implementadas aún no superan la formación instrumentalista de las TIC y no han logrado ahondar en la fundamentación pedagógica, comunicativa e investigativa, tal como se plantea desde la normatividad.

Por otra parte, Contreras y González presentan un resultado de investigación titulado "Nuevas funciones docentes para la gestión del conocimiento en la Web Social", cuyo estudio indica que el docente en la actual sociedad de la información ha tenido que cambiar su rol debido a la incidencia de las tecnologías de la información y la comunicación en el contexto de la educación superior. En ese sentido, su quehacer pedagógico y didáctico va cambiando en relación con dinámicas mucho más 
colaborativas con sus educandos. La doctora Pozo Vinueza Pozo de la Escuela Superior Politécnica de Chimborazo de Ecuador en su investigación, "La formación investigativa interdisciplinaria de los estudiantes universitarios con el empleo de las tecnologías de la información y la comunicación (TIC) y su dinámica", revela carencias y limitaciones existentes en el abordaje teórico del vínculo formación investigativa percibido desde la interdisciplinariedad y las TIC en los procesos formativos universitarios.

Finalmente, los docentes Ramos, López y Llamas presentan su trabajo de investigación "Relación entre la creatividad, la memoria inmediata y lógica en relación con el rendimiento académico en educación secundaria", en el cual pretenden analizar la relación entre creatividad y la memoria (inmediata y lógica), y a su vez éstas con el rendimiento académico en adolescentes de educación secundaria.

Ahora bien, en nombre de la Revista Academia $y$ Virtualidad, agradecemos a todos los autores de los artículos, a los grupos y redes de investigación, a los árbitros, a los miembros del Comité Editorial, del Comité Científico, $\mathrm{y}$ al equipo de traductores, revisores metodológicos, revisores técnicos y correctores de estilo, por contribuir al excelente nivel académico y científico de nuestra publicación. También informar a nuestros lectores que la revista fue indizada en este semestre por las bases bibliográficas Biblat, SciLit y Doaj, lo que motiva a continuar por el horizonte trazado por el Director, el Comité Editorial y el Comité Científico. 


\section{Editorial \\ The future of indexed national journals}

Henry Acuña Barrantes

This time we are offering you Vol.10 No.1, i.e. the first of two issues scheduled this year. Our task for this issue by Revista Academia $y$ Virtualidad is assuming new guidelines that Publindex implemented for journals working reflective processes, results and conclusions related to scientific research in and from the academic environment.

During the last three years, Revista Academiay Virtualidad has undergone significant changes thanks to the unconditional support by the Office of the Vice-Rectory for Research and the Faculty of Distance Studies; also, the time devoted to editor in chief, the implementation of the Open Journal System (OJS), the acquisition of DOI, the editors' training, and other critical issues of this qualification process have been valuable. Everything has had a positive impact on the growth and visibility of our journal since it is a reference work in most cities in the country and in more than 80 countries in five continents (Source: Google Analytics.)

\section{Statistics, Revista Academia y Virtualidad (2014-2016)}

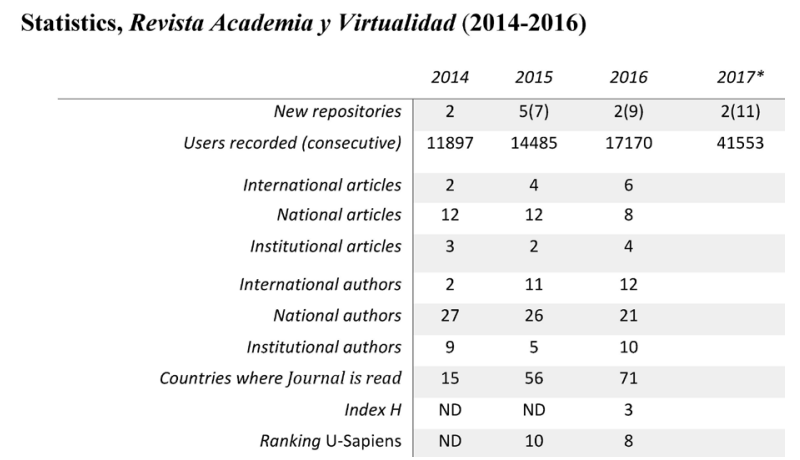

\section{Our Commitment}

Publindex -as a regulator entity of national scientific journals- provides guidelines for the current 2017 ranking (C, B, A2, and A1). Universities supporting journals dissemination or producing new scientific publications, must evaluate qualitatively and quantitatively their volumes, having as important reference their mission and vision since they can record visibility and impact, although sometimes not be classified at national level but internationally. For that reason the importance and precision about what universities want with their issues.

There is a lot of things to discuss on this topic but now I will address only one concern: the visibility and impact upon readers, specifically students who want to find out the first-hand the most recent research results by some professors-researchers who 'unfortunately' fail to get interested in this type of creative and analytical exercise and do not encourage their students to read them.

However, our concern, specifically by Revista Academia y Virtualidad and Faculty itself including professors and research groups, is always promoting the search, so students may read, are interested in and updated on issues by our Journal. To that extent, interest has been generated by creative research processes related to academia and virtual issues in order to improve education in several professional settings. Therefore, the future perspective of a Journal like ours (which it is also the concern of most scientific publications in our country) is always a continuous qualification, closely linked to the domestic reference system for evaluation of scientific publications featured 
by accuracy, criteria and quality. All of this, together with the human resources, the conditions and the academy interest, which in a way will be coherent to the strong contemporary dynamics marked by the latest technologies.

With this volume I've just finished an important cycle working for our Journal. Since January 2014 the time until today has been fulfilled where I remained as an editor of Academia y Virtualidad. In my job I found out many synergies contributing to strength the Journal, besides enriching my background with new knowledge and experiences. Since then our publication has been typified by scientific objectivity papers and essays, either by one or more authors, selected by an exhaustive process and based on equally demanding quality criteria, to enter and consolidate an indexed database.

Finally, from now I will be working with other tasks at the university. But from now on the responsibility of the next issue will be in charge by the Engineer PhD Carlos Gaviria Mendoza, whom I wish the best success in this fascinating editor role. I only have to thank the members of our Editorial Board and Scientific Committee, the evaluating referees who continually supported and made my work something enriching as well as the team of translators and methodological and technical proofreaders for their contribution to qualify each issue thanks to their experience.

$* * * * * * * * * * * * * * * * * * * * * * * * * * * * * * * * * * * *$

$* * * * * * * * * * * * * * * * * * * * * * * * * * * * * *$

We continue with our traditional presentation of the papers. In this volume 10 No. 1, Revista Academia y Virtualidad offers you articles by leading national and international researchers. The content exposes and follows guidelines and rules by Journal Board, headed by Engineer Martin Villamil Rozo, Dean of the Faculty of Distance Studies, and the Editorial Committee and Scientific Committee.
Below, nine papers of research, reflection and review as a result of research exercises. On the one hand, some of them show a work based upon different educational concerns, particularly those involving ICTs and all those problem areas that in one way or another are underpinning virtual education. In the first paper, the researchers Vargas and Garcia, Universidad de Ibagué, offer the scientific research article entitled "Managerial skills-A challenge for higher education," whose study aims to establish the importance of generic and specific skills by the financial manager, by taking the Tuning project in Latin AmericaEurope and the GRIICA Colombia project as reference. On the other hand, Professor Anívar Chaves Torres, in his research "Distance education, responding to the educational needs of the twenty-first century," focuses on distance education as a viable response before an increasing education demand particularly by people who cannot access a face-to-face education because of different circumstances.

Researchers Rodríguez and Vílchez offer the paper "The value-added as a quality indicator in university academic programs using census test results" whose study aims at determining value-added as a quality indicator of an academic program taking into account two points in the time of the students' academic life, from a cohort and a reasoned explanation built of this assessment including the contribution by the university. Continuing with the articles in this volume, Dr. Issa Fontalvo, in her research paper "Leadership skills to innovation culture related to management of universities at Santa Marta District," says that main purpose of her research was analyzing the leadership skills for a culture of innovation by managers at the universities of Santa Marta District. The development of her work indicates that management is not able to perceive relevant aspects and facts, lacking the reflexive management before of complex situations, besides a breakdown in communication. Then workshops or training courses may be recommended to develop skills in order to achieve a behavior change 
towards innovative strategic thinking.

Professors Amaya and Rincon, at their turn, offer a research result about "Assessment of academic self-regulation by undergraduates in the distance virtual mode at Corporación Universitaria Minuto de Dios- UNIMINUTO, aimed to evaluate strategies targeted and implemented to academic self-regulation at that entity.

Regarding work "ICTs regulations and strategies for teacher training," researchers Lopez, Rojas, Correa and Arbelaez of the Universidad de la Amazonia show that the goal focused to ICTs training is getting education competitiveness, quality and equity. The teachers' training strategies have been made by levels but privileged the cascade technique. One of their conclusions indicates that several training strategies implemented do not surpass yet the instrumentalist focus of the ICTs and have not been able to delve into the pedagogical, communicative and research foundation, as rules say.

On the other hand, Contreras and Gonzalez present a research result entitled "New teaching roles regarding knowledge management in the social web," whose study indicates that teachers in the current information society have had to change their role due to the impact by the ICTs upon the higher education. In that sense, their pedagogical and didactic task has been changing in relation to more collaborative dynamics with their trainees. Dr. Pozo Vinueza of the Escuela Superior Politécnica de Chimborazo at Ecuador in her research, "The cross-disciplinary research training by college students using the information and communications technologies -ICTs- and its dynamics" reveals some deficiencies and restrictions in the theoretical basis between research training (from cross-disciplinary perspective) and the ICTs, which impact the training processes at the university.

Finally, professors Ramos, Lopez and Llamas present their research work "A relationship among creativity, immediate-and-logic memory and academic achievement in secondary school," where they analyze a relationship between creativity and immediateand-logical memory, and in turn these ones related to the academic achievement by adolescents in secondary school.

Now, on behalf of Revista Academia y Virtualidad, we thank all the authors of papers, research teams and networks, referees, members of the Editorial Board, the Scientific Committee, and the team of translators and methodological and technical proofreaders for their contribution to get a better academic and scientific level of our Journal. Also we inform our readers that our publication has been indexed this semester in databases Biblat, SciLit and Doaj, something which motivates us to continue the horizon outlined by Director, the Editorial Board and the Scientific Committee.

\section{Revista Academia y Virtualidad January-June 2017}




\section{Editorial \\ O futuro das revistas nacionais indexadas}

Henry Acuña Barrantes

Desta vez estamos apresentando o Vol.10 No. 1 que corresponde ao primeiro das edições programadas para o 2017. Nossa tarefa nesta edição da Revista Academia y Virtualidad consiste em assumir os novos lineamentos que Publindex estabeleceu para revistas dedicadas a processos, resultados e conclusões reflexivas em pro da pesquisa cientifica em e desde o entorno acadêmico.

A Revista Academia y Virtualidad, nestes três últimos anos, já registrou mudanças importantes por conta do apoio incondicional da Vice-reitoria de Pesquisa e da Faculdade de Estudos a Distância; assim mesmo, tem sido valiosos o tempo dedicado e facilitado ao editor em chefe, a implementação do Open Journal System (OJS), a aquisição dos DOI, as capacitações aos seus editores, entre outros aspetos vitais para todo este processo de qualificação. Todo isso já repercutiu positivamente no crescimento e visibilidade da nossa revista, pois até hoje é uma publicação de consulta na maioria das cidades do território nacional e em mais de 80 países dos cinco continentes (Consultado em: Google Analytics).

Estadísticas, Revista Academia y Virtualidad (2014-2016)

\begin{tabular}{r|cccc} 
& 2014 & 2015 & 2016 & $2017^{*}$ \\
\hline Novos repositórios & 2 & $5(7)$ & $2(9)$ & $2(11)$ \\
Consecutivo de usuários & 11897 & 14485 & 17170 & 41553 \\
Artigos internacionais & 2 & 4 & 6 & \\
Artigos nacionais & 12 & 12 & 8 & \\
Artigos institucionais & 3 & 2 & 4 & \\
Autores internacionais & 2 & 11 & 12 & \\
Autores nacionais & 27 & 26 & 21 & \\
Autores institucionais & 9 & 5 & 10 & \\
Países que consultam a revista & 15 & 56 & 71 & \\
Índice H & ND & ND & 3 & \\
Ranking U-Sapiens & ND & 10 & 8 &
\end{tabular}

Fonte: Revista Academia y Virtualidad ( ${ }^{*}$ fevereiro)

\section{O nosso compromisso}

Publindex, no seu papel de regulador das revistas científicas nacionais, emite os direcionamentos para sua classificação vigente a 2017 (C, B, A2, A1). As universidades que apoiam a difusão de revistas ou desejam produzir novas publicações científicas, devem realizar avaliação tanto qualitativa quanto quantitativa dos seus volumes, tendo como referente importante sua missão e visão, uma vez que pode se registrar visibilidade e impacto, no entanto em alguns casos não estar classificada a nível nacional embora estivelo internacionalmente; daí a importância e claridade do que pretendem as universidades com suas edições.

Respeito deste tema da muito para falar, mas pelo instante abordarei um só aspecto: a visibilidade e impacto nos leitores, especificamente os estudantes que desejam ter resultados de pesquisa recentes e de primeira ordem provenientes de alguns professorespesquisadores, quem "infelizmente" não conseguem se interessar neste tipo de exercício criador e analítico e não motivam aos seus estudantes a consulta-las.

Contudo, o nosso interesse, o da Revista Academia y Virtualidad, e a própria Faculdade com seus docentes e grupos de pesquisa consiste em impulsar a busca permanente para que seus estudantes consultem, se interessem, e estejam adiantados nas temáticas que maneja a revista. Deste jeito, já se gerou interesse pelos processos de pesquisa $\mathrm{e}$ criativos relacionados com a academia e a virtualidade a fim de melhorar a educação nos diversos cenários profissionais. Daí que nossa perspectiva no futuro duma revista 
como a nossa (cuja preocupação é a mesma da maioria das publicações científicas em nosso país), consistir em sempre ter presente uma qualificação permanente, dentro do sistema nacional de referência para a avaliação de publicações científicas com rigor, critério e qualidade. Todo isso, além do recurso humano, as condições e o interesse da academia, que de qualquer jeito vão se refletir na coerência com uma grande dinâmica contemporânea atirada pelas tecnologias de ponta.

Com este volume fecho um ciclo importante dirigindo a Revista. Já se completou o tempo desde janeiro 2014 até hoje que permaneci como editor de Academia y Virtualidad. Nesta função achei muitas sinergias que contribuíram na consolidação da revista, além de enriquecer minha bagagem pessoal com novos conhecimentos e experiências. Nossa publicação desde então tem se caraterizado por expor artigos e ensaios com rigor cientifico, provenientes de um ou vários autores, por meio de um processo de seleção exaustivo baseado em critérios de qualidade igualmente exigentes, para ingressar e consolidar uma base de dados indexada.

Por último, a partir deste momento estarei noutras atividades próprias da universidade. $\mathrm{E}$ agora, a responsabilidade da próxima edição ficara nas mãos do engenheiro Carlos Gaviria Mendoza $\mathrm{PhD}$, a quem desejo os melhores sucessos neste fascinante papel como editor. Só me resta agradecer aos membros dos nossos Comités Editorial e Científico, aos árbitros avaliadores quem com seu apoio permanente fizeram minha tarefa enriquecedora, igualmente que os pesquisadores, expositores, expertos em propostas, equipes de revisão técnica, correição de estilo e tradução, que desde sua experiência contribuíram a qualificar cada edição.

$* * * * * * * * * * * * * * * * * * * * * * * * * * * * * * * * * * * *$ $* * * * * * * * * * * * * * * * * * * * * * * * * * * * * *$

Em seguida a nossa tradicional apresentação dos artigos. Neste volume 10 No. 1, a Revista
Academia y Virtualidad entrega artigos de pesquisadores de destaque nacional e internacional. O conteúdo expõe e continua os lineamentos e orientações estabelecidos pela Direção da Revista, dirigida pelo engenheiro Martin Villamil Rozo, Decano da Faculdade de Estudos a Distância do Comitê Editorial e do Comitê Científico.

Em seguida, apresentam-se nove artigos de pesquisa, reflexão e revisão, resultadas de exercícios de pesquisa. De um lado destacamse artigos que mostram um trabalho baseado nas diferentes problemáticas educativas, em particular aquelas que involucram as TIC e todos aqueles aspetos que, dum jeito ou outro, conformam a base da educação virtual. No primeiro deles, as pesquisadoras Vargas y García, da Universidad de Ibagué, apresentam o artigo de pesquisa científica nomeado "Competências diretivas, um repto para a educação superior" cujo estudo tem como objetivo determinar o nível de importância das competências genéricas e específicas do administrador financeiro, tomando como referente ao projeto Tuning em Latino América-Europa e o projeto GRIICA Colômbia. De outro lado, o professor Anívar Chaves Torres, em seu trabalho de pesquisa "A educação a distância como resposta às necessidades educativas do século XXI", centra-se em estabelecer como a educação a distância erige-se como resposta viável à ampla demanda de educação, em particular por pessoas que devido a diferentes circunstâncias não têm acesso a educação presencial.

Os pesquisadores Rodríguez e Vílchez apresentam um artigo de pesquisa, nomeado "Valor agregado como indicador de qualidade em programas acadêmicos universitários utilizando resultados de probas de qualidade", cujo estudo consistiu em determinar o valor agregado como indicador de qualidade dum programa acadêmico a partir de dois momentos da vida acadêmica dos estudantes de uma coorte e a construção duma explicação razoada da dita valoração a partir do aporte que faz a universidade. Continuando com os artigos deste volume, a doutora Issa Fontalvo, 
em seu trabalho de pesquisa "Habilidades da liderança para uma cultura de inovação na gerência das universidades do Distrito de Santa Marta" indica que o propósito fundamental de sua pesquisa foi analisar as habilidades de liderança para uma cultura da inovação na gerência das universidades do Distrito de Santa Marta. No decorrer do trabalho indicase que a gerência não possui capacidade para perceber que alguma coisa tem passado sem ser avistada, carece de manejo de situações difíceis de jeito reflexivo e não escuta; então recomenda-se elaborar oficinas ou cursos de formação sobre habilidades gerenciais para uma cultura de inovação a fim de obter uma mudança no comportamento gerencial por meio de um pensamento estratégico inovador. Por sua vez, os professores Amaya e Rincón apresentam um resultado de pesquisa sobre a "avaliação da auto regulação acadêmica em estudantes de pré-graduação da Corporación Universitaria Minuto de Dios-UNIMINUTO, na modalidade virtual distância", cujo estudo teve como alvo avaliar estratégias de auto regulação acadêmica aplicada pelos estudantes de pré-graduação do nomeado estabelecimento.

Respeito do trabalho "Normatividade e estratégias de formação de professores nas tecnologias da informação e comunicação", os pesquisadores López, Rojas, Correa y Arbeláez da Universidade da Amazônia, expõem que o propósito da formação nas TIC é de obter competividade, qualidade e equidade na educação. As estratégias de formação de professores têm se realizado por níveis e privilegiara-se a técnica de cascata. Uma das suas conclusões mostra que algumas das estratégias de formação aplicadas ainda não superaram a formação instrumentalista das TIC e não têm conseguido afundar na fundamentação pedagógica, comunicativa e de pesquisa, tal qual fica estipulado na normatividade.

De outro lado, Contreras e González apresentam um resultado de pesquisa nomeado "Novas funções docentes para a gestão do conhecimento na Web Social", cujo estudo mostra que o docente na atual sociedade da informação já teve de mudar seu papel devido a incidência das tecnologias da informação e a comunicação no contexto da educação superior, Neste sentido seu quefazer pedagógico e didático vai mudando em relação a dinâmicas muito mais colaborativas com seus educandos. A doutora Pozo Vinueza da Escuela Superior Politécnica de Chimborazo, Equador em sua pesquisa, "A formação pesquisadora interdisciplinar dos estudantes universitários com o emprego das tecnologias da informação e a comunicação (TIC) e sua dinâmica", revela carências e limitações existentes na abordagem teórica do vínculo formação pesquisadora percebido desde o interdisciplinar e as TIC nos processos formativos universitários.

Finalmente, os docentes Ramos, López y Llamas apresentam seu trabalho de pesquisa "Relação entre a criatividade, a memória imediata e lógica, em relação ao rendimento académico em educação secundária", no qual pretendem analisar a relação entre criatividade e a memória (imediata e lógica), e por sua vez estas com o rendimento acadêmico em adolescentes de educação secundária.

Então agora, em nome da Revista Academia y Virtualidad, agradecemos a todos os autores dos artigos, aos grupos e redes de pesquisa, aos árbitros, aos membros do Comitê Editorial, do Comitê Científico, e à equipe de tradutores, revisores metodológicos, revisores técnicos e corretores de estilo, por contribuírem ao excelente nível acadêmico e científico de nossa publicação. Também informar a nossos leitores que a revista foi indexada neste semestre pelas bases bibliográficas Biblat, SciLit, Doaj, o que motiva a continuar no horizonte traçado pelo Diretor, o Comitê Editorial e o Comitê Científico.

Revista Academia y Virtualidad Janeiro-Junho de 2017 